\title{
TNF-A protection of hippocampal neurons from kainic acid induced neurodegeneration is associated with up-regulation of NFKB and AKT as well as down-regulation of p38 MAPK signaling molecules
}

\begin{abstract}
Background: Previously, our study showed that TNF- $\alpha$ plays a protective role in kainic acid (KA) induced neurodegeneration in vivo in mice. Here, we further clarified the protective role of TNF- $\alpha$ in KA-induced hippocampal neuronal damage in vitro and elucidated the potential signaling pathways
\end{abstract}

Methods: Hippocampal neurons were isolated from embryonic 16 days (E16) TNF- $\alpha$ knockout (KO) and wild-type (WT) mice with C57BL/6 background, respectively, and exposed to KA with and without recombinant TNF- $\alpha$, as well as anti-TNF- $\alpha$ antibody. After 24-hours exposure to KA, lactate dehydrogenase $(\mathrm{LDH})$ production and neurotoxicity were detected for evaluating neuronal survival rates. The production of nitric oxide (NO) from supernatants and the expression of nuclear factor kappa B (NFкB), inhibitor of NFкB alpha $(\mathrm{I} \kappa \mathrm{B} \alpha), \mathrm{p} 38$ mitogen-activated protein kinase (MAPK) and AKT in hippocampal neurons were measured.

Results: Comparing with WT mice, the neurons of TNF- $\alpha$ KO mice showed more susceptibility to KA-induced neurotoxicity, as demonstrated by higher production of $\mathrm{LDH}$ and lower neuronal survival rates, as well as elevated NO production. It is also evidenced that pre-blocked TNF- $\alpha$ molecule in the neuron cultures of WT mice with antiTNF- $\alpha$ antibody significantly enhanced the production of LDH and NO, and decreased the neuronal survival rate. In contrast, the neurons from WT mice pre-exposed to recombinant TNF- $\alpha$ were more resistant to KA induced neurotoxicity. TNF- $\alpha$ deficiency down-regulated phospho-IкB $\alpha, \mathrm{NF}_{\kappa} \mathrm{B}$, total AKT and phospho-AKT, as well as up-regulated phospho-p38 MAPK expressions after KA insult. The reverse results were achieved in WT hippocampal neurons with TNF- $\alpha$ pre-administration.

Conclusion: Our findings demonstrated an association between the protective effect of TNF- $\alpha$ on neurons as assessed following KA insult, with the up-regulation of NFKB and AKT, as well as down-regulation of p38 MAPK signaling molecules..

Keywords: tnf- $\alpha$, kainic acid, neurotoxicity, hippocampal neuron, AKT, p38 mapk
Volume I Issue 2 - 2015

\author{
Xiang-Yu Zheng, 1,2 Naheed Amir, ${ }^{3}$ Hong- \\ Liang Zhang, ${ }^{1,2}$ Sheikh Azimullah, ${ }^{3}$ Bengt \\ Winblad, ${ }^{2}$ Abdu Adem, ${ }^{3}$ Jie Zhu I, ${ }^{2}$ \\ 'Department of Neurology, The First Hospital of Jilin University, \\ China \\ 2Department of Neurobiology, Karolinska Institute, Sweden \\ ${ }^{3}$ Department of Pharmacology, United Arab Emirates University, \\ United Arab Emirate
}

Correspondence: Jie Zhu, Department of Neurobiology, Care Sciences and Society, Karolinska Institute, Karolinska University Hospital Huddinge, Novum, plan 5, SE-I4I 86, Stockholm, Sweden, Tel 46858585494, Fax 46858585470, Email Jie.Zhu@ki.se

Received: November 15, 2014 | Published: May 22, 2015
Abbreviations: $\mathrm{AD}$, alzheimer disease; $\mathrm{CNS}$, central nervous system; I $\mathrm{B} \mathrm{B} \alpha$, inhibitor of nuclear factor kappa $\mathrm{b}$ alpha; KA, kainic acid; LDH, lactate dehydrogenase; MAPK, mitogen-activated protein kinase; MTT, 3-(4,5-dimethylthiazol-2-yl)- 2,5-diphenyltetrazolium bromide; NFkB, nuclear factor kappa b; NO, nitric oxide; ROS, reactive oxygen species; TNF- $\alpha$, tumor necrosis factor- $\alpha$; WT, wild type

\section{Introduction}

The inflammatory cytokines, especially tumor necrosis factor- $\alpha$ $(\mathrm{TNF}-\alpha)$, are mainly released by microglia and astrocytes after central nervous system (CNS) insult ${ }^{1}$ and are intricately involved in neuronal pathology. ${ }^{2}$ As a well documented acute-phase inflammatory cytokine, TNF- $\alpha$ was first described by Carswell et al., ${ }^{3}$ in 1975, and its function was defined as anti-tumour activity. However, TNF- $\alpha$ is highly pleiotropic and has been implicated in a multitude of neurological pathologies and diseases including multiple sclerosis (MS) ${ }_{1}^{4}$ cachexia-induced cerebellar degeneration, ${ }^{5}$ acute spinal cord injury ${ }^{6}$ and neurodegenerative disorders, such as Alzheimer disease (AD). ${ }^{7}$ In contrast to its detrimental role, it is also evidenced that TNF- $\alpha$ plays a protective role in global ischemia ${ }^{8}$ and in acute cerebral contusion models. ${ }^{9}$ Therefore, it is speculated that TNF- $\alpha$ could play a double role in the diseases of the CNS, which may depend on the signal transduction pathway that is activated.

Glutamate is the most powerful and abundant excitatory neurotransmitter in the CNS. Excess production of glutamate is an important underlying cause of neuronal damage in many neurodegenerative disorders, including AD and Parkinson's disease (PD). Kainic acid (KA), a non-degradable analog of glutamate, has 30 -fold more potency in neurotoxicity than glutamate. ${ }^{10}$ By activating kainite receptors, KA elicits the increase of intracellular $\mathrm{Ca}^{2+}$, production of reactive oxygen species (ROS) and mitochondrial dysfunction, which result in neuronal apoptosis and necrosis. ${ }^{11} \mathrm{KA}$ administration also enhances the release of endogenous excitatory amino acids that secondarily activate microglia and astrocytes, which can secrete ROS and inflammatory molecules to worsen 
the neuronal injury. Activated astrocytes and microglia as well as neurons may also secrete chemokines to recruit microglia and astrocytes into the inflammatory site. ${ }^{12}$ Previously, our study revealed that KA insult results in more severe seizures, greater hippocampal neurodegeneration and increased glial activation in TNF- $\alpha$ deficient mice, suggesting that TNF- $\alpha$ may play a protective role in KAinduced neurotoxicity. ${ }^{13}$ Since the role of TNF- $\alpha$ in neurodegenerative disorders is controversial, in the present study, we further clarified the role of TNF- $\alpha$ in the excitotoxic neurodegeneration in vitro and elucidated its possible involvement of signalling pathways in TNF- $\alpha$ knockout (KO) mice and C57BL/6 wild-type (WT) mice by using primary neuronal cell cultures. In addition, we studied the effects of exogenous TNF- $\alpha$ and blocking TNF- $\alpha$ molecule by anti-TNF- $\alpha$ antibody on KA insult of neuronal cells from WT mice.

\section{Materials and methods}

\section{Animals}

The TNF- $\alpha$ KO mice and WT mice at embryonic day 16 (E16) were purchased from Taconic (Taconic, Demark) and kept at Faculty of Medicine \& Health Sciences, United Arab Emirates (UAE) University, UAE and the animal facilities of Karolinska University Hospital, Huddinge, Sweden. All mice were housed on a 12 hours (h) light-dark schedule with water and food available at libitum. The present study was performed in accordance with the published international health guidelines and local legislation for experimental animal ethics.

\section{Preparation and culture of primary hippocampal neurons}

Primary cultures of hippocampal neurons were isolated at E16 from mice according to the method by Fath et al. ${ }^{14}$ Briefly, the brains were kept in sterile ice-cold phosphate-buffered saline (PBS), and thereafter, hippocampi were carefully dissected out. The hippocampi were moved to a tube with Neurobasal medium including $1 \%$ L-glutamine, 2\% B27 supplement (all from Invitrogen, USA). B27 was used to inhibit the proliferation of glial cells during cultivation of the hippocampal neurons. Tissue fragments were dissociated mechanically with a Pasteur pipette until the cell suspension was formed. The hippocampal neuronal cells were counted and seeded in 6-well plates coated with $50 \mu \mathrm{g} / \mathrm{ml}$ poly-D-lysine (Sigma-Aldrich, Stockholm, Sweden) at a density of $2 \times 0^{5}$ cells per well. The cells were cultured at $37^{\circ} \mathrm{C}$ in a $5 \% \mathrm{CO}_{2} / 95 \% \mathrm{O}_{2}$ incubator. On the seventh day, cultures were exposed to KA (Opika-1, Ocean Produce International, Scheburne, Nova Scotia, Canada) dissolved in PBS (10mg/1.3ml). The concentration of KA was $200 \mu \mathrm{M}$ per well. After co-culture with KA for $24 \mathrm{~h}$, ice-cold lysis buffer, containing $137 \mathrm{mM} \mathrm{NaCl}, 20 \mathrm{mM}$ Tris $\mathrm{HCl}(\mathrm{pH} 8.0), 1 \%$ NP40 10\% glycerol, 1mM PMSF $10 \mu \mathrm{g} / \mathrm{ml}$ aprotinin, $1 \mu \mathrm{g} / \mathrm{ml}$ leupetin, $0.5 \mathrm{mM}$ Sodium vanadate was used to harvest the hippocampal neurons for subsequent experiments. The supernatants were collected and frozen at $-70^{\circ} \mathrm{C}$ until used.

The hippocampal neurons from WT mice were cultured as described above and were pre-exposed to $50 \mathrm{ng} / \mathrm{ml}, 100 \mathrm{ng} / \mathrm{ml}$ and $200 \mathrm{ng} / \mathrm{ml}$ recombinant mouse TNF- $\alpha$ (rm-TNF- $\alpha$ ) or anti-TNF- $\alpha$ monoclonal antibody (mab), respectively (Sigma-Aldrich, Stockholm, Sweden) on the seventh day for $24 \mathrm{~h}$. The concentrations of rm-TNF- $\alpha$ and anti-TNF- $\alpha$ mab, and the cultured time (24h) had the optimal effects as assessed in several pilot experiments. The cultures were then exposed to KA for another $24 \mathrm{~h}$ before harvesting.

\section{Measurement the level of lactate dehydrogenase (LDH) and neurotoxicity}

The total protein concentrations were measured by using the bicinchoninic acid (BCA) protein assay kit (Bio-Rad, Sweden). Standard curve was obtained by using bovine serum albumin (BSA, Sigma, Sweden) solutions at concentrations of 6, 3, 1.5, 0.75, 0.375, 0.1875 , and $0 \mathrm{mg} / \mathrm{ml}$, respectively. The concentrations of proteins were quantified from the standard curve. LDH production was detected in the culture supernatants $24 \mathrm{~h}$ after KA administration by using Cytotoxicity Detection Kit (LDH, Roche, Switzerland), and the kit directions were followed. The results were presented as "relative value of LDH production versus total protein".

Twenty-four hours after KA administration, neuronal viability was determined by the colorimetric metabolic dye 3-(4,5-Dimethylthiazol2-yl)-2,5-diphenyltetrazolium bromide (MTT) assay as described previously; ${ }^{15} 1.25 \mathrm{mg} / \mathrm{mL}$ MTT solution was added to each well of a 96-well plate. After $3 \mathrm{~h}$ of incubation, cells were lysed by adding $120 \mu \mathrm{L}$ of isopropyl- $\mathrm{HCl}$ solution $(37 \% \mathrm{HCl} /$ isopropyl alcohol: $1 / 166)$ for $15 \mathrm{~min}$. The absorbance of each well was recorded at $595 \mathrm{~nm}$ with an automated ELISA reader.

\section{Detection of NO production}

After $24 \mathrm{~h}$ incubation with KA, the supernatants were collected and snap-frozen for detecting NO production by using the modified Griess reagent (Sigma, Sweden). The instructions provided by the manufacturer were followed. Standard curve was achieved by using sodium nitrite (Sigma) solutions at concentrations of 9, 3, 1, 0.33, $0.11,0.033$, and $0 \mu \mathrm{g} / \mathrm{ml}$, respectively. The results were presented as "relative value of total nitrite/nitrate versus total protein".

\section{Western blotting}

Cultured hippocampal neurons after $24 \mathrm{~h}$ stimulation by KA were harvested and proteins were obtained. The protein samples were boiled at $100^{\circ} \mathrm{C}$ for $10 \mathrm{~min}$ and centrifuged at $12000 \mathrm{rpm}$ for $10 \mathrm{~min}$. Protein concentrations were quantified by using the bicinchoninic acid (BCA) protein assay kit (Bio-Rad, Sweden). For protein separation, $50 \mu \mathrm{g}$ of each sample were electrophoresed on a $12 \%$ polyacrylamide gel and transferred to nitrocellulose membranes. The membranes were then blocked in 5\% nonfat dry milk in PBS-Tween 20 for $1 \mathrm{~h}$ at room temperature with gentle agitation. After blocking, the membranes were incubated with appropriate primary antibody rabbit anti-phospho-p38 mitogen-activated protein kinase (MAPK) $(0.5 \mu \mathrm{g} / \mathrm{ml})(\mathrm{R} \& \mathrm{D}$ system, UK), phospho-IкB $\alpha(1: 1000)$, rabbit antimouse NFKB (1:2000), rabbit anti-mouse AKT (1:1000), rabbit antimouse phospho-AKT (1:1000) or rabbit anti-mouse $\beta$-actin (1:1000) (all from Cell signaling, In Vitro Sweden AB, Sweden), overnight at $4^{\circ} \mathrm{C}$. After extensive washing in PBS-Tween 20 , membranes were incubated with peroxidase-conjugated secondary antibodies for $1 \mathrm{~h}$ at room temperature. Then the membranes were rinsed again. Enhanced chemiluminescent (ECL) Western blotting detection reagents (Bio-Rad) were used for exposure according to the manufacturer's instructions. Densitometric analysis was performed using the ImageJ program (NIH, USA).

\section{Data presentation and statistics}

Each set of data was presented as mean value \pm standard deviation (SD). The statistical program for social sciences (SPSS) 11.5 (SPSS, USA) was used to analyze the data. Kruskal-Wallis test was used to 
compare values among groups followed by Mann-Whitney U test to compare values between groups. All tests were two-tailed, and the level of significance was set to $\mathrm{p}<0.05$.

\section{Results and discussion}

\section{TNF- $\alpha$ protects neurons against KA-induced excitotoxicity}

To assess the effect of TNF- $\alpha$ on hippocampal neurons after KA-induced neurotoxicity, the hippocampal neuronal cultures were challenged with $200 \mu \mathrm{M}$ KA. Neuronal viability was determined after $24 \mathrm{~h}$ following KA exposure by MTT assay. In WT mice, KA administration reduced neuronal cell survival to $48.6 \pm 9.2 \%$ when compared with unexposed WT mice neurons (set to 100\%). The viability of neurons from TNF- $\alpha \mathrm{KO}$ mice after KA insult was reduced to $36.3 \pm 7.8 \%$, which was significantly decreased as compared with neurons from WT mice after incubation with $\mathrm{KA}(\mathrm{p}<0.05$, Figure 1A). $\mathrm{rm}-\mathrm{TNF}-\alpha$ at the concentrations of $50 \mathrm{ng} / \mathrm{ml}, 100 \mathrm{ng} / \mathrm{ml}$ and $200 \mathrm{ng} /$ $\mathrm{ml}$ increased the neuronal cell survival to $56.3 \pm 15.3 \%, 66.3 \pm 18.3 \%$ and $71.3 \pm 11.9 \%$, respectively in WT mice cultures. The hippocampal neuron survival rates in WT mice cultures were significantly increased after KA insult with TNF- $\alpha$ pre-exposure at $100 \mathrm{ng} / \mathrm{ml}$ and $200 \mathrm{ng} / \mathrm{ml}$ concentrations when compared with WT mice neurons exposed to KA, but without TNF- $\alpha$ pre-exposure. However, a lower concentration of TNF- $\alpha(50 \mathrm{ng} / \mathrm{ml})$ did not influence neuronal cell survival rate in the WT mice cultures exposed to KA $(\mathrm{p}<0.05$, Figure $1 \mathrm{~B})$.

Pre-blocked TNF- $\alpha$ molecule with anti-TNF- $\alpha$ antibody at 50ng/ $\mathrm{ml}, 100 \mathrm{ng} / \mathrm{ml}$ and $200 \mathrm{ng} / \mathrm{ml}$ in the neurons from WT mice reduced the neuronal cell survival to $47.3 \pm 14.4 \%, 40.3 \pm 13.3 \%$ and $37.3 \pm 12.9 \%$, respectively. The WT mice hippocampal neuron survival rates were significantly decreased after anti-TNF- $\alpha$ antibody blocking with $100 \mathrm{ng} / \mathrm{ml}$ and $200 \mathrm{ng} / \mathrm{ml}$ concentrations when compared with WT mice neurons without anti-TNF- $\alpha$ antibody blocking prior to KA insult. However, a lower concentration of anti-TNF- $\alpha$ antibody (50ng/ $\mathrm{ml}$ ) did not influence neuronal cell survival rate in the cultures from WT mice exposed to KA ( $p<0.05$, Figure 1C).
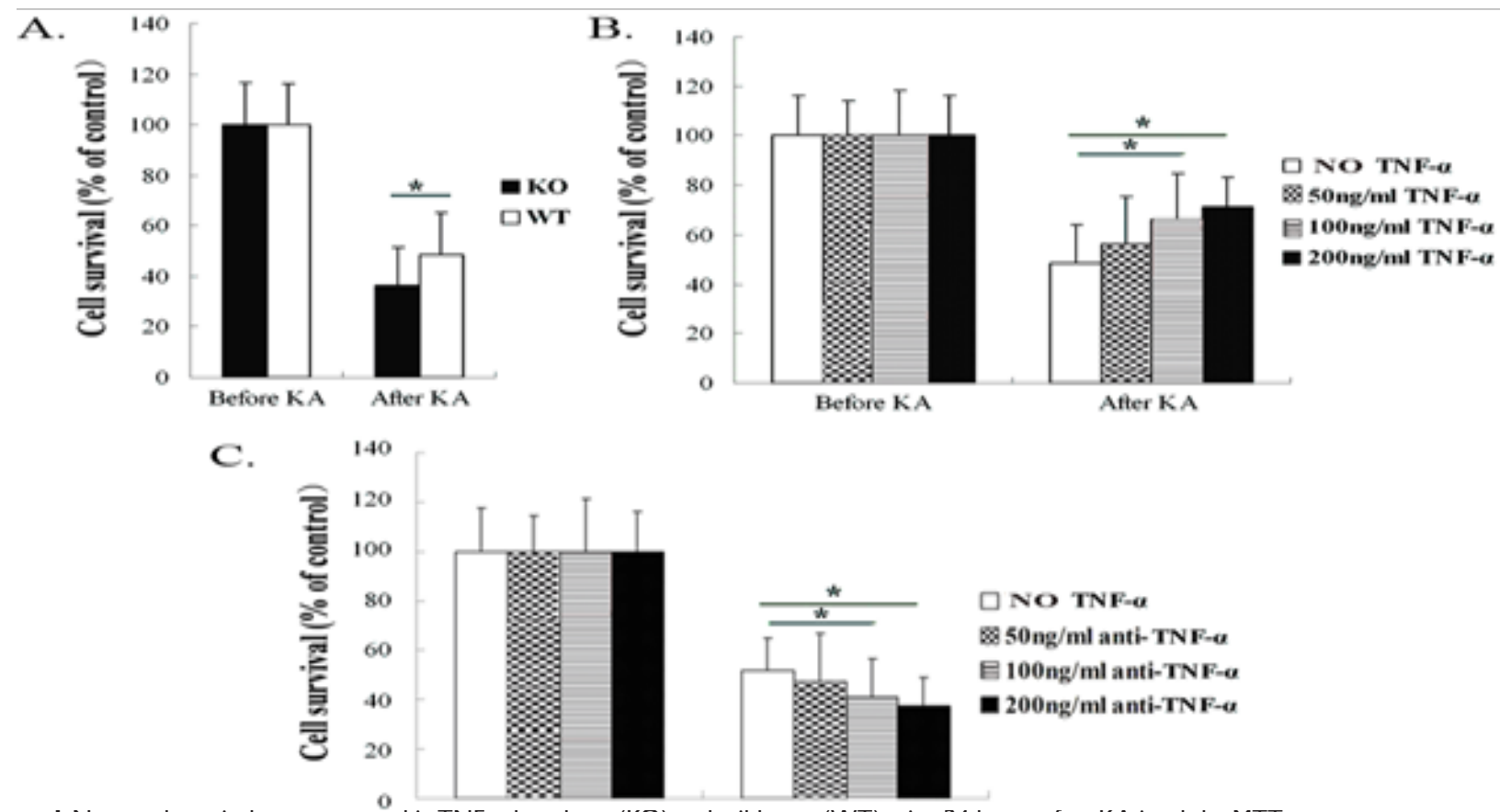

Figure I Neuronal survival was measured in TNF- $\alpha$ knockout (KO) and wild-type (WT) mice 24 hours after KA insult by MTT assay.

Figure IA After KA insult, neurons from KO mice exhibited significantly reduced cell survival compared with neurons from WT mice.

Figure IB After KA administration, neurons from WT mice that had been pre-exposed to TNF- $\alpha$ at $100 \mathrm{ng} / \mathrm{ml}$ and $200 \mathrm{ng} / \mathrm{ml}$, respectively, showed significantly enhanced cell survival compared with neurons from WT mice without TNF- $\alpha$ pre-exposure.

Figure IC Anti-TNF- $\alpha$ antibody blocking with $100 \mathrm{ng} / \mathrm{ml}$ and $200 \mathrm{ng} / \mathrm{ml}$ concentrations, respectively, markedly reduced cell survival as compared with WT mice neurons without anti-TNF- $\alpha$ antibody blocking and following exposure to KA. Data are presented as mean values $\pm S D$. $N=5$ in each group.

$* \mathrm{P}<0.05$.

TNF- $\alpha$ decreases LDH production after KA insult in hippocampal cultures

$\mathrm{LDH}$ is an indicator for loss of cell membrane integrity, and high levels of LDH in the culture supernatants implied an increased number of dead cells or cells with damaged plasma membranes. Therefore, elevated LDH activity in supernatants directly correlates to the damaged degree of neurons over time. In the present study, LDH production was detected in hippocampal neuron supernatants of TNF- $\alpha$ KO and WT mice after KA insult for $24 \mathrm{~h}$. Our results showed that neurons from TNF- $\alpha \mathrm{KO}$ mice displayed higher production of LDH after KA insult, when compared with neurons from WT mice $(p<0.05)$; however, there was no difference between the two groups of mice before KA exposure (Figure 2A). Pre-incubation of the neurons 
from WT mice with $100 \mathrm{ng} / \mathrm{ml}$ and $200 \mathrm{ng} / \mathrm{ml} \mathrm{rpm}-\mathrm{TNF}-\alpha$ showed significantly decreased LDH production compared with the neurons without TNF- $\alpha$ pre-exposure $(\mathrm{p}<0.05)$. However, a lower TNF- $\alpha$ concentration $(50 \mathrm{ng} / \mathrm{ml})$ did not affect $\mathrm{LDH}$ production in the neurons from WT mice exposed to KA (Figure 2B). Pre-exposure of neurons with anti-TNF- $\alpha$ antibody at $100 \mathrm{ng} / \mathrm{ml}$ and $200 \mathrm{ng} / \mathrm{ml}$ concentrations increased LDH production, while a lower concentration of anti-TNF- $\alpha$ antibody $(50 \mathrm{ng} / \mathrm{ml})$ did not affect the LDH activity compared with the neurons without anti-TNF- $\alpha$ antibody blocking (Figure 2C).

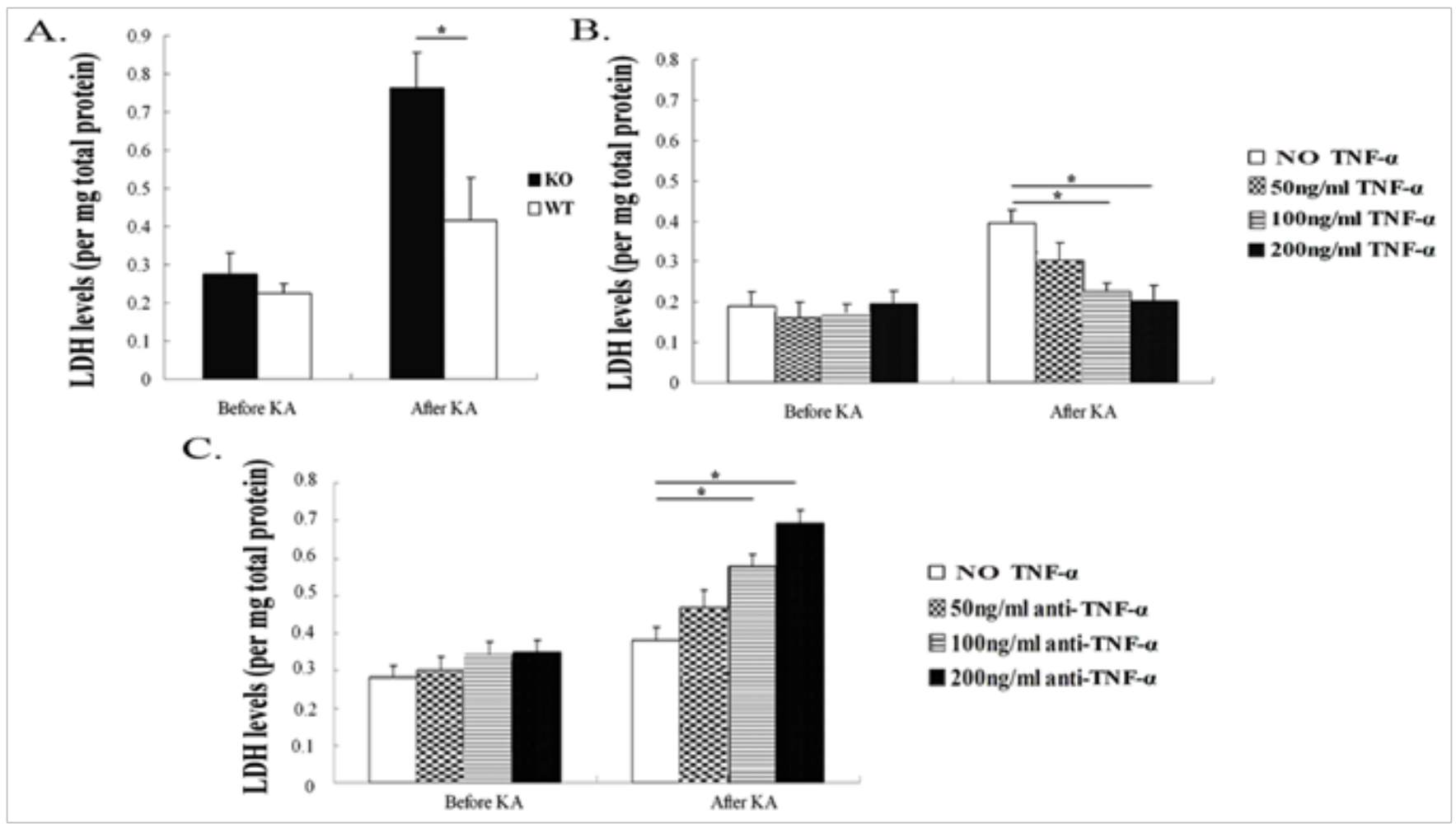

Figure 2 Lactate dehydrogenase (LDH) production in hippocampal neuron cultures from TNF- $\alpha$ KO andWT mice after KA insult.

Figure 2A TNF- $\alpha$ deficiency increased production of LDH 24 hours after KA insult.

Figure 2B LDH production was decreased with TNF- $\alpha(100 \mathrm{ng} / \mathrm{ml}$ and $200 \mathrm{ng} / \mathrm{ml}$, respectively) compared to WT mice neurons without pre-exposure to TNF- $\alpha$.

Figure 2C LDH level was increased in WT mice neurons pre-exposed to anti-TNF- $\alpha$ antibody $(100 \mathrm{ng} / \mathrm{ml}$ and $200 \mathrm{ng} / \mathrm{ml}$, respectively) when compared with WT mice neurons without anti-TNF- $\alpha$ antibody addition. Data are presented as mean values \pm SD. $N=5$ in each group.

$* \mathrm{P}<0.05$.

TNF- $\alpha$ reduces nitric oxide (NO) production in hippocampal cultures

Before and 24h after KA insult, the NO production was measured in hippocampal neuronal supernatants of TNF- $\alpha \mathrm{KO}$ and WT mice. Hippocampal neurons from TNF- $\alpha \mathrm{KO}$ mice had increased KAinduced NO production in supernatants $(\mathrm{p}<0.05)$; there was no difference in neuronal NO production between the two groups of mice before KA insult (Figure 3A). After pre-exposure to TNF- $\alpha$ in WT mice neurons, $\mathrm{NO}$ production was lower compared with neurons from WT mice without TNF- $\alpha$ pre-exposure (Figure 3B). Hippocampal neurons pre-exposed to anti-TNF- $\alpha$ antibody (100ng/ml and 200ng/ $\mathrm{ml}$ ) increased the expression of NO (Figure 3C).

TNF-a up-regulates phospho-inhibitor of nuclear

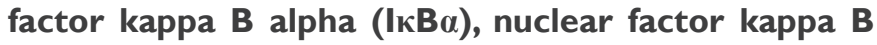
(NFKB) and AKT expression in hippocampal cultures

To better understand the mechanism behind the increased neurotoxicity in TNF- $\alpha$ deficient mice after KA insult, we employed
Western blotting to examine phospho-IкB $\alpha, \mathrm{NF \kappa B}$, AKT and phospho-AKT expression in hippocampal neurons among all groups of mice (WT and KO mice before and 24h after KA insult). Twentyfour hours after addition of KA to the cultures, the neurons isolated from KO mice showed significantly lower phospho-IкB $\alpha, \mathrm{NF} \kappa \mathrm{B}$, AKT and phospho-AKT expression than did neurons from WT mice $(\mathrm{p}<0.05$, (Figure 4A-4C) (Figure 5A-5C). The same results were found after co-culture with anti-TNF- $\alpha$ antibody $(\mathrm{p}<0.05$, Figure $4 \mathrm{D}-4 \mathrm{~F}$, Figure 5D-5F). In the hippocampal neurons from WT mice

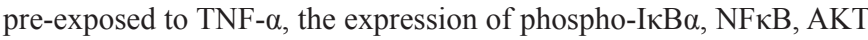
and phospho-AKT was higher than in neuron cultures from WT mice without TNF- $\alpha$ stimulation followed by co-culture with $\mathrm{KA}$ ( $\mathrm{p}<0.05$, (Figure 4G-4I, Figure 5G-5I).

\section{TNF- $\alpha$ down-regulates phospho-p38 mitogen- activated protein kinase (MAPK) expression in hippocampal cultures}

We also employed Western blotting to examine phospho-p38 MAPK expression after KA administration. Phospho-p38 MAPK 
expression was detectable in hippocampal neurons among all groups of mice (WT and KO mice before and 24h after KA insult). Twentyfour hours after KA insult, the neurons from KO mice exhibited distinctly higher phospho-p38 MAPK expression than neurons from WT mice $(p<0.05$, Figure 6A \& 6B). Pre-blockade with antiTNF- $\alpha$ antibody $(200 \mathrm{ng} / \mathrm{ml})$ significantly increased the production of phospho-p38 MAPK $(\mathrm{p}<0.05$, Figure 6C \& 6D). Taken together, the results suggest that TNF- $\alpha$ down-regulated phospho-p38 MAPK expression. However, no significant difference was found among the four groups of WT mice (with and without TNF- $\alpha$ pre-exposure) before and after KA insult (Figure 6E \& 6F).

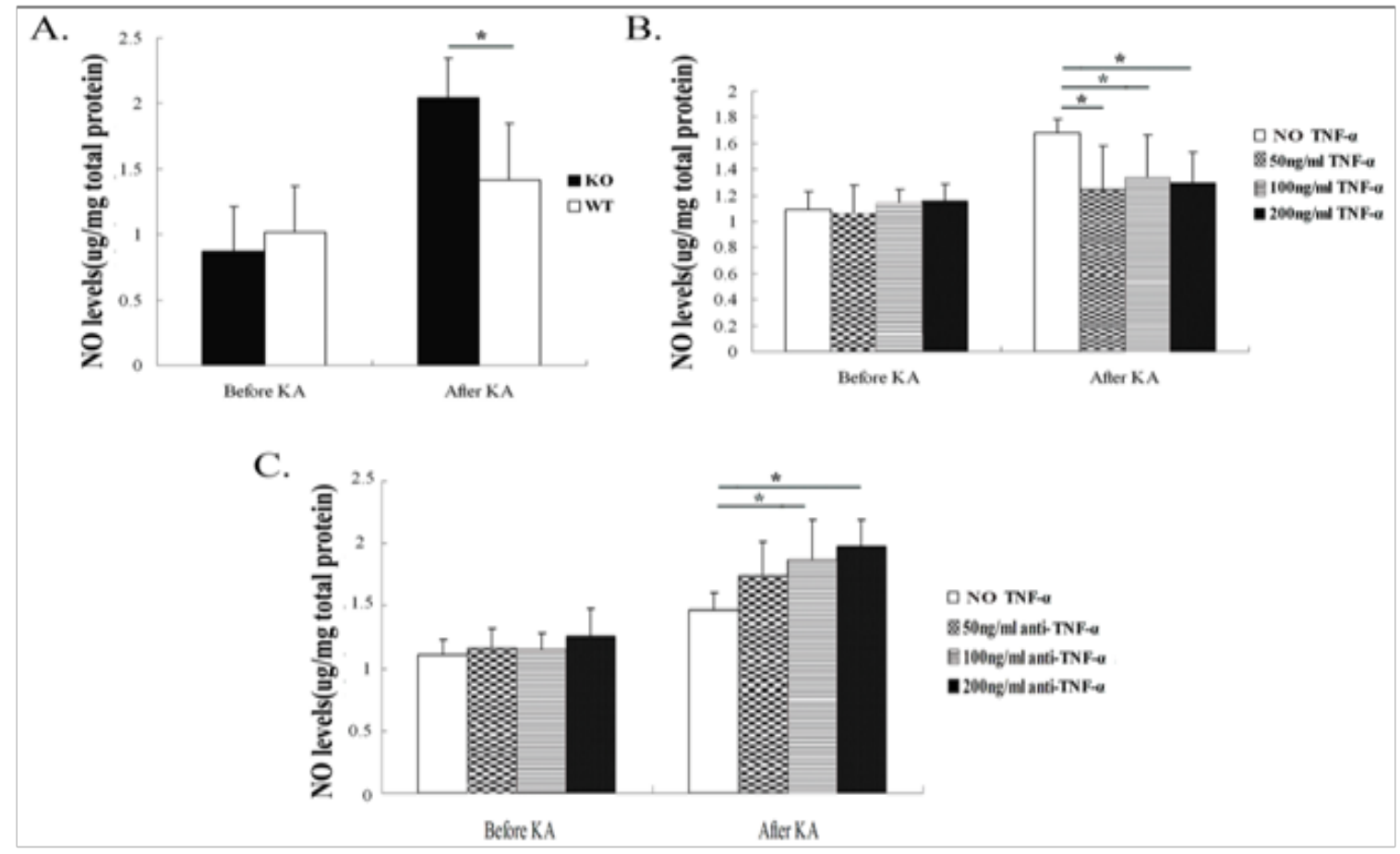

Figure 3 Nitric oxide (NO) production in hippocampal neurons after exposure to KA. Twenty-four hours after KA insult, NO production was measured in hippocampal neuron culture supernatants of TNF- $\alpha$ KO and WT mice.

Figure 3A TNF- $\alpha$ deficiency increased KA-induced NO production in hippocampal neurons 24h after KA insult.

Figure 3B Pre-exposure to TNF- $\alpha$ at $50 \mathrm{ng} / \mathrm{ml}, 100 \mathrm{ng} / \mathrm{ml}$ and $200 \mathrm{ng} / \mathrm{ml}$, respectively, decreased NO production in WT mice hippocampal neurons after KA insult.

Figure 3C Pre-exposure to anti-TNF- $\alpha$ antibody $(100 \mathrm{ng} / \mathrm{ml}$ and $200 \mathrm{ng} / \mathrm{ml})$ increased NO production in WT mice hippocampal neurons after KA insult. Data are presented as mean values $\pm \mathrm{SD}$. $\mathrm{N}=5$ in each group. $* \mathrm{P}<0.05$.

In the present study, we found that hippocampal neurons from TNF- $\alpha$ deficient mice showed more susceptibility to KA-induced neurotoxicity, as demonstrated by significantly increased LDH and NO production, and decreased neuronal survival in the primary cultures. Additionally, TNF- $\alpha$ deficiency clearly down-regulated the expression of phospho-IкB $\alpha, \mathrm{NF} \kappa \mathrm{B}, \mathrm{AKT}$ and phospho-AKT, and upregulated phospho-p38 MAPK expression in hippocampal neurons after KA insult. In hippocampal neurons from WT mice, the blocking of TNF- $\alpha$ increased LDH and NO production, and aggravated KAinduced neurotoxicity. Furthermore, blocking TNF- $\alpha$ with anti-TNF- $\alpha$ antibody distinctly down-regulated the production of phospho-I $\mathrm{B} \alpha$, $\mathrm{NF \kappa B}, \mathrm{AKT}$ and phospho-AKT in hippocampal cultures, as well as up-regulated the expression of phospho-p38 MAPK. However, hippocampal neurons from WT mice pre-exposed to TNF- $\alpha$ demonstrated decreased LDH and NO expression, and attenuated KA-induced neurotoxicity. TNF- $\alpha$ stimulation distinctly up-regulated the production of phospho-I $\kappa \mathrm{B} \alpha, \mathrm{NF \kappa B}, \mathrm{AKT}$ and phospho-AKT in hippocampcal cultures. The role of TNF- $\alpha$ in neurodegenerative disorders is diverse and complex. Over-expression of TNF- $\alpha$ in transgenic mice is associated with the occurrence of age-dependent neurodegenerative changes and sporadic spontaneous seizures. ${ }^{16}$
Antagonism of TNF- $\alpha$ using a monoclonal antibody helped neuronal survival. ${ }^{17}$ However, TNF- $\alpha$ deletion has also shown interesting effects on neuronal maturation and arborization. Golan et al. ${ }^{18}$ found that the dendritic arborization complexity of pyramidal neurons residing within the $\mathrm{CA} 1$ and $\mathrm{CA} 3$ regions of the hippocampus was reduced in the absence of TNF- $\alpha$ expression. ${ }^{18}$

KA can elicit selective neuronal death in the brain of rodents ${ }^{19,20}$ and seriously impacted the hippocampus, which is due to the high density of kainate receptors (KARs) in the CA3 region. ${ }^{21}$ The activation of KARs can induce the production of ROS and damage the function of mitochondria in the region. ${ }^{22} \mathrm{KA}$ stimulated the release of $\mathrm{LDH}$, an indicator for loss of cell membrane integrity, suggesting KA induced damage to mitochondrial function. ${ }^{23}$ In this study, hippocampal neurons from TNF- $\alpha \mathrm{KO}$ mice displayed higher expression of LDH and lower cell survival than WT mice after $24 \mathrm{~h}$ KA insult, which indicated that hippocampal neurons from TNF- $\alpha \mathrm{KO}$ mice are more sensitive to KA induced neurotoxicity. The blockade of TNF- $\alpha$ activity in neuron cultures from WT mice increased LDH and reduced cell survival rate, which indicated TNF- $\alpha$ plays a protective role in neurons that received KA insult. 


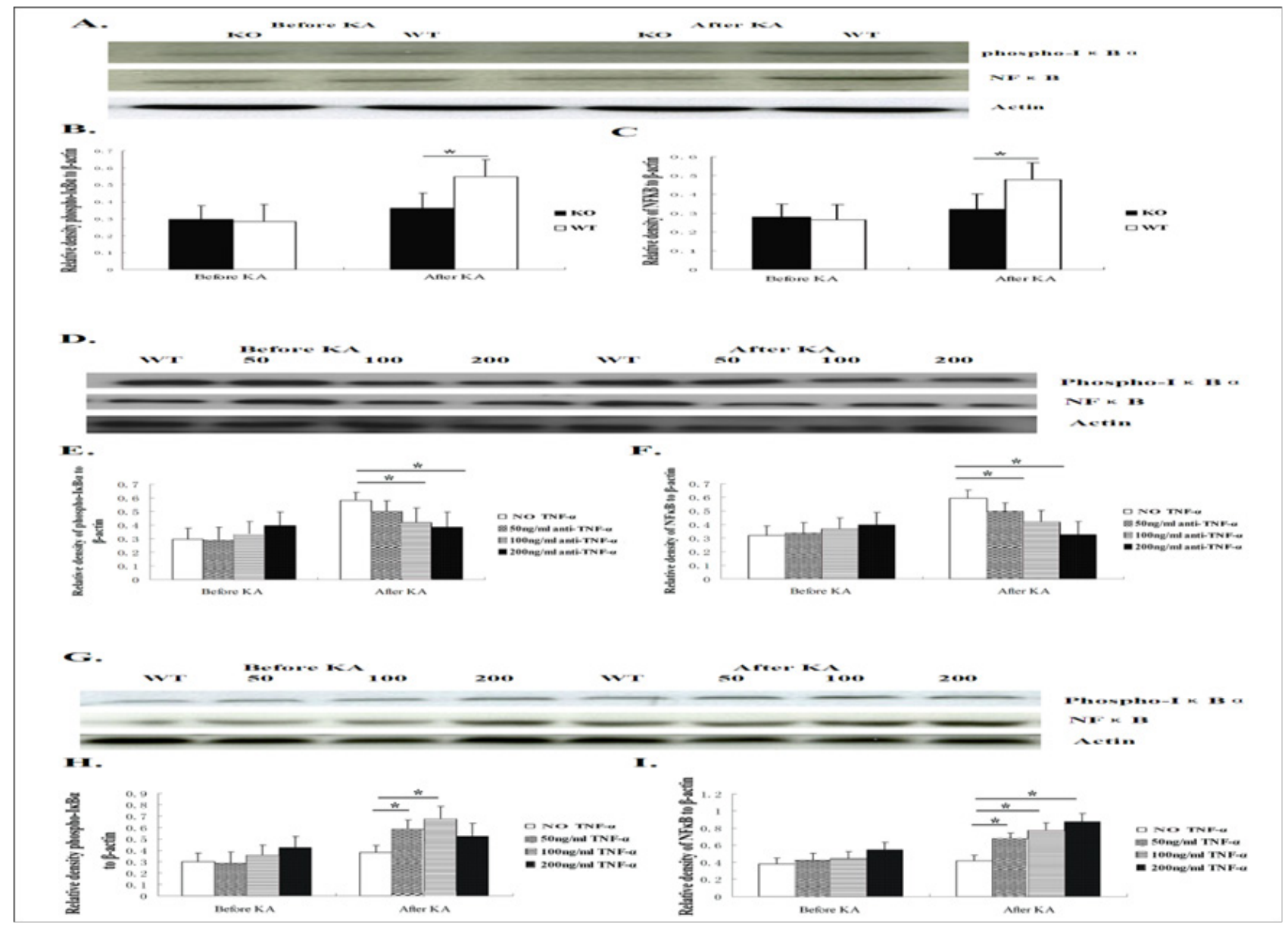

Figure 4 Phospho-I $\mathrm{B} \mathrm{B} \alpha$ and $\mathrm{NF} \kappa \mathrm{B}$ expression in hippocampal neurons after exposure to KA was detected by Western blotting.

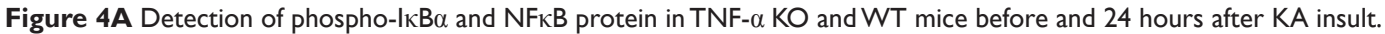

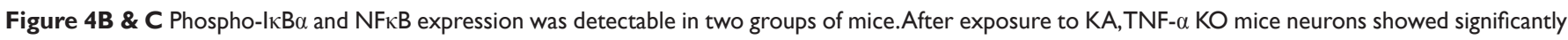
lower phospho- $\mathrm{I}_{\mathrm{B}} \mathrm{B} \alpha$ and $\mathrm{NF} \kappa \mathrm{B}$ expression than WT mice neurons. There was no difference for phospho-I $\mathrm{B} \alpha$ and $\mathrm{NF} \kappa \mathrm{B}$ expression between neuron cultures from the two groups of mice before KA administration.

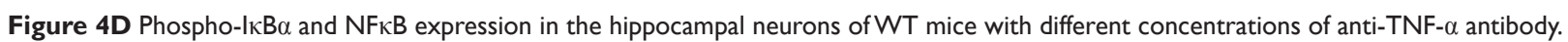

Figure 4E \& F Twenty-four hours after KA insult, phospho-IKB $\alpha$ and NFKB expression was detectable in four groups of mice. After KA administration, the neurons from WT mice with anti-TNF- $\alpha$ antibody blocking at $100 \mathrm{ng} / \mathrm{ml}$ and $200 \mathrm{ng} / \mathrm{ml}$, respectively, showed significantly lower phospho-l $\kappa \mathrm{B} \alpha$ expression than WT mice neurons without anti-TNF- $\alpha$ antibody blocking.

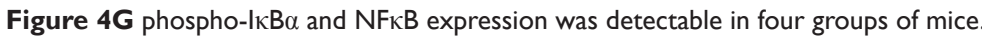

Figure 4H \& I After KA insult, the neurons of WT mice with TNF- $\alpha$ at the concentration of I00ng/ml and 50ng/ml, respectively, showed significantly higher phospho-I $\kappa \mathrm{B} \alpha$ and $\mathrm{NF} \kappa \mathrm{B}$ expression than those without TNF- $\alpha$ pre-stimulation. Data are presented as mean values $\pm S D$. $N=5$ in each group. $* \mathrm{P}<0.05$.

NO has been involved in many physiological and pathological processes within the CNS and can be formed enzymatically from L-arginine by inducible NO synthase (iNOS) in neuroglia. ${ }^{24} \mathrm{KA}$ administration increases the generation of ROS and reactive nitrogen species (RNS) by neuroglia. There is growing evidence that free radical generation plays a key role in the neuronal damage. ${ }^{25}$ Elevated production of NO by increased activity of iNOS is thought to participate in KA-induced neurotoxicity. ${ }^{26}$ The iNOS-deficient mice were resistant to KA-induced neuronal death. Similarly, pre-exposure to an iNOS inhibitor significantly suppressed KA-induced neuronal death in the hippocampal CA3 area. ${ }^{27}$ In our study, we observed that $\mathrm{KA}$ is capable of increasing the production of NO in hippocampal neurons from KO mice or from WT mice with blocking TNF- $\alpha$ activity. However, TNF- $\alpha$ stimulation significantly reduced the production of NO in WT mice neurons after KA insult.

TNF- $\alpha$ exerts its biological functions through binding its two receptors, TNF receptor (TNFR) 1 (p55) and TNFR2 (p75). ${ }^{28}$ Our previous study demonstrated that TNFR1 may mediate a protective signaling in KA-induced neurotoxicity. ${ }^{29} \mathrm{~A}$ differential role of TNFR1 and TNFR2 has been reported, in that hippocampal neurons responding to TNF- $\alpha$ by activation of TNFR1 alone induced both NFאB activation and cell death, whereas activation of TNFR2 was found to stimulate p38 MAPK expression. ${ }^{30}$ The signaling pathway of $\mathrm{p} 38$ MAPK can regulate gene expression and lead to increased production of proinflammatory cytokines by a number of different mechanisms. ${ }^{31}$ 
P38 MAPK activity has also been associated with the induction of apoptosis in numerous cell types and in response to a multitude of cellular stresses. ${ }^{32}$ Our present results reported that TNF- $\alpha$ deficiency or blocking TNF- $\alpha$ activity with anti-TNF- $\alpha$ antibody enhanced the expression of p38 MAPK after KA insult. However, pre-exposure to different concentrations of rm-TNF- $\alpha$ did not influence the expression of p38 MAPK after KA exposure. It is speculated that p38 MAPK is not sensitive to exogenous TNF- $\alpha$ administration. We concluded that KA-induced neurotoxicity in hippocampal cultures may partly be due to the activation of 338 MAPK signaling pathway, but this pathway may not be the predominant signaling pathway in this condition.

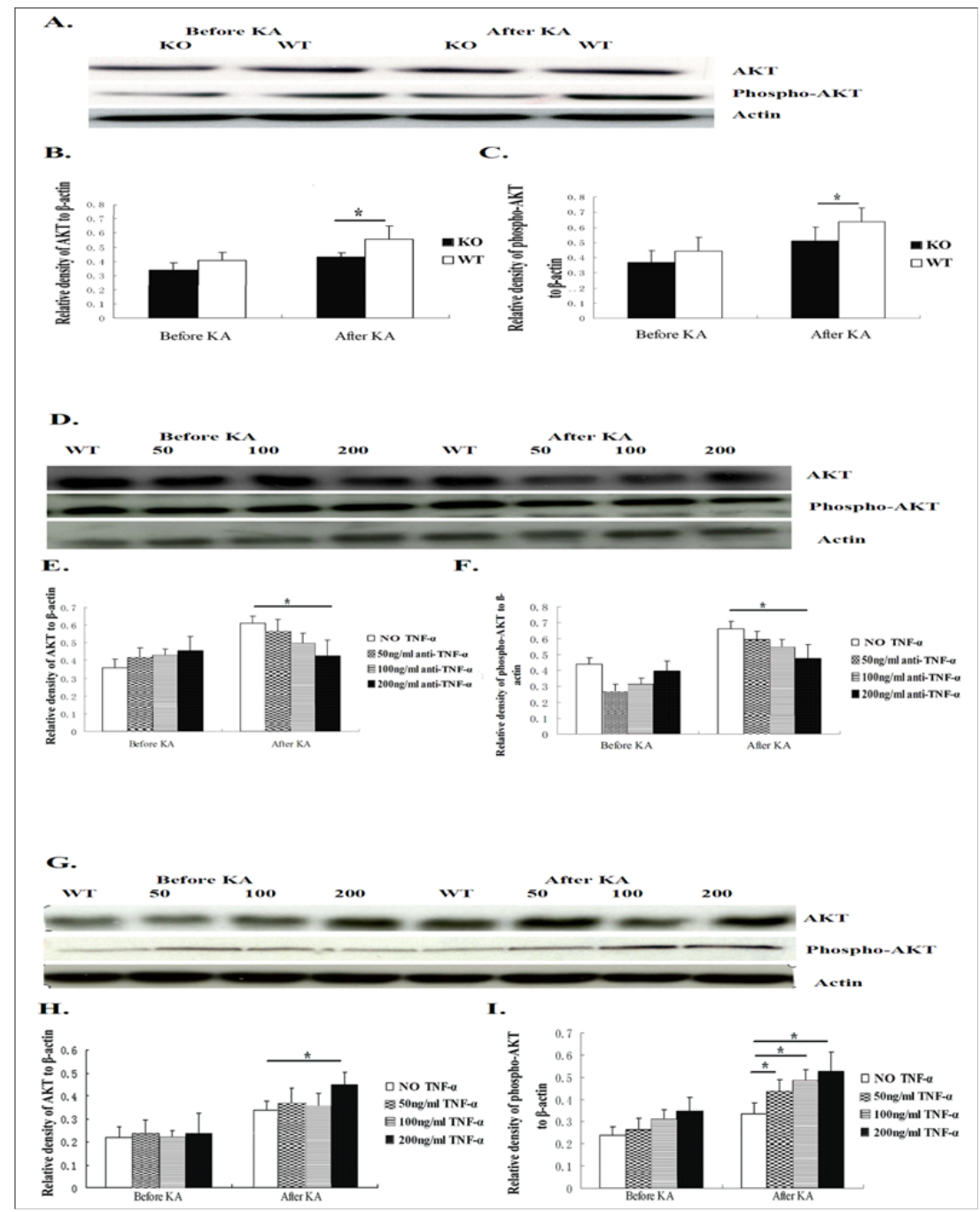

Figure 5 AKT and phospho-AKT expression in hippocampal neurons after exposure to KA was measured by Western blotting.

Figure 5A AKT and phosphor-AKT expression from hippocampal neurons of WT mice and KO mice.

Figure 5B \& C After 24 hours of KA exposure, TNF- $\alpha$ KO mice showed significantly lower AKT and phospho-AKT expression than WT mice.There was no difference between the neuron cultures from the two groups of mice before KA insult.

Figure 5D AKT and phospho-AKT were detected in hippocampal neurons of WT mice with different concentrations of anti-TNF- $\alpha$ antibody,

Figure 5E \& F Twenty-four hours after exposure to KA, the neurons from WT mice that were pre-exposed to anti-TNF- $\alpha$ antibody at $200 \mathrm{ng} / \mathrm{ml}$ showed significantly lower AKT expression than the neurons from WT mice without anti-TNF- $\alpha$ antibody blocking.After KA insult, the neurons of WT mice pre-exposed to anti-TNF- $\alpha$ antibody with $200 \mathrm{ng} / \mathrm{ml}$ showed significantly lower phospho-AKT expression than WT mice neurons without anti-TNF- $\alpha$ antibody pre-exposure.

Figure 5G The level of AKT and phosphor-AKT protein in neurons from WT mice with TNF- $\alpha$ pre-exposure. Figure $\mathbf{5 H}$ Twenty-four hours after addition of KA to neuron cultures, the neurons of WT mice pre-exposed to TNF- $\alpha$ at $200 \mathrm{ng} / \mathrm{ml}$ showed significantly higher AKT expression than neurons from WT mice without pre-exposure to TNF- $\alpha$.

Figure 5I After KA insult, neuron cultures from WT mice that were pre-exposed to TNF- $\alpha$ at $200 \mathrm{ng} / \mathrm{ml}, 100 \mathrm{ng} / \mathrm{ml}$ and $50 \mathrm{ng} / \mathrm{ml}$, respectively, showed significantly higher phospho-AKT expression than neuron cultures from WT mice without pre-exposure to TNF- $\alpha$. Data are presented as mean values $\pm S D$. $N=5$ in each group.

$* \mathrm{P}<0.05$. 
$\mathrm{NF} \kappa \mathrm{B}$ is a heterodimeric transcription factor that regulates cell differentiation, proliferation and survival. ${ }^{33} \mathrm{NF} \kappa \mathrm{B}$ activation may play a major role in TNF- $\alpha$ promoting neuro protection against glutamate-induced neurotoxicity in cortical neurons. ${ }^{34}$ In the present study, TNF- $\alpha$ deficiency and blocking TNF- $\alpha$ significantly decreased expression of $\mathrm{NF} \kappa \mathrm{B}$, while TNF- $\alpha$ administration increased $\mathrm{NF} \kappa \mathrm{B}$ expression in hippocampal neurons, indicating that TNF- $\alpha$ may play a neuro protective role via activation of NFKB pathway. However, this finding is contrary to our previous study in vivo that TNF- $\alpha$ may play a protective role in KA-induced neurotoxicity via down-regulation of NFkB signaling pathway. ${ }^{13}$ Regarding the opposite results, we delineated several potential possibilities. Firstly, the two studies were carried out in different conditions, one in vivo and another in vitro. Secondly, it may be due to the different sample timing for detecting the expression of NFkB. Thirdly, in our previous study, the expression of NFKB was as a common result from the activated glial cells and neurons. But the present study is focusing on the function of neurons only, i.e. the expression of NFkB was from neurons, not glial cells.

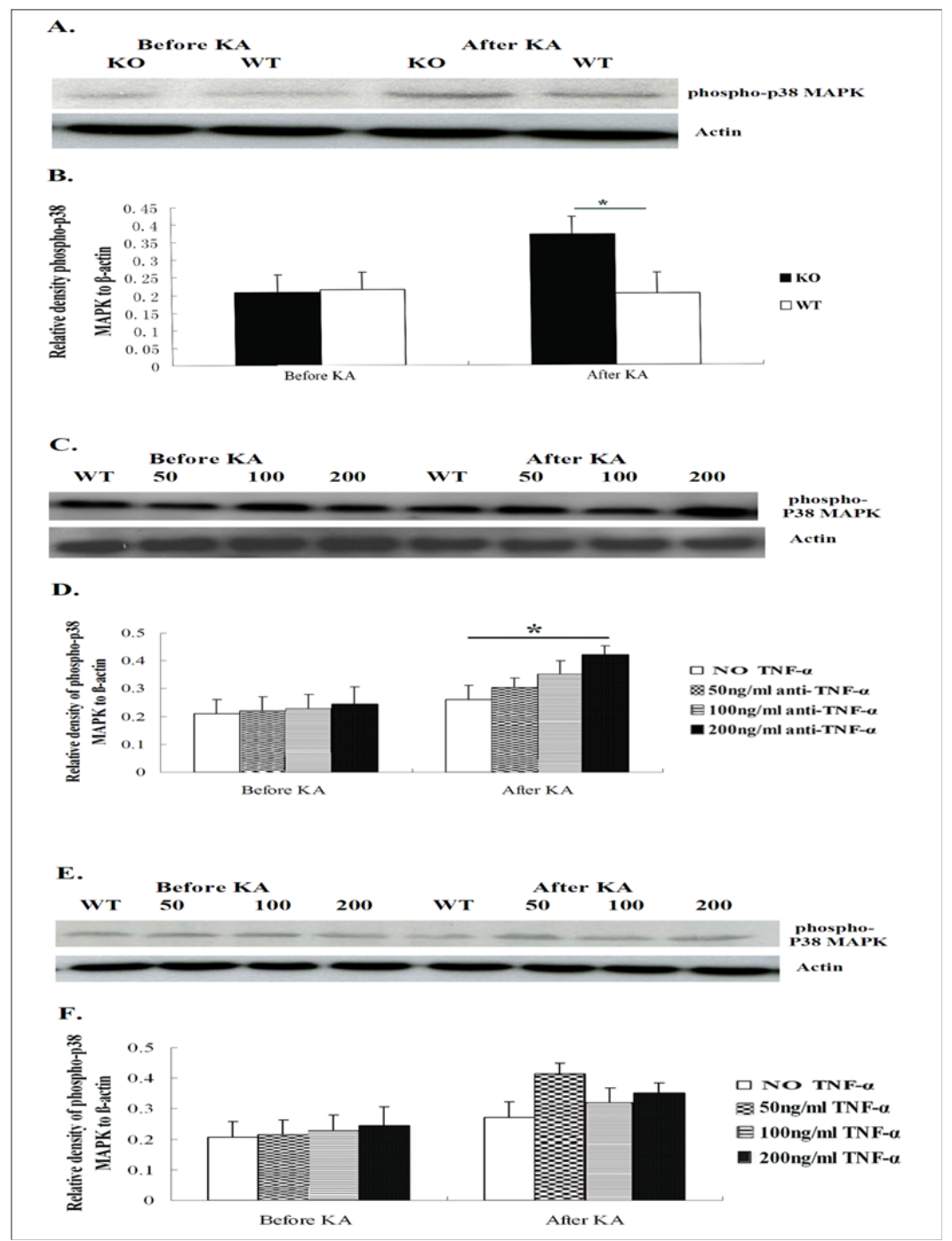

Figure 6 Phospho-p38 MAPK expression in hippocampal neurons was detected by Western blotting.

Figure 6A Detection of phospho-p38 MAPK protein in WT and KO mice.

Figure 6B After 24 hour exposure to KA, neurons from TNF- $\alpha$ KO mice showed significantly higher phospho-p38 MAPK expression than neurons from WT mice. No difference was found between neuron cultures from KO and WT mice before KA insult.

Figure 6C Phospho-p38 MAPK protein expression in neurons from WT mice with anti-TNF- $\alpha$ antibody blocking.

Figure 6D Pre-exposure of neurons from WT mice to anti-TNF- $\alpha$ antibody at 200ng/ml significantly increased phospho-p38 MAPK expression.

Figure 6E Detection of phospho-p38 MAPK in hippocampal neurons of WT mice with TNF- $\alpha$ pre-incubation and KA stimulation.

Figure 6F No difference was found in neurons from WT mice with and without TNF- $\alpha$ pre-exposure before and after KA insult. Data are presented as mean values $\pm S D$. $N=5$ in each group.

$* \mathrm{P}<0.05$. 
Protein kinase B (PKB)/AKT pathway is an essential pathway for cell survival, since AKT is necessary for neuronal survival and plays a key role in up-regulation of anti-apoptotic proteins.$^{35}$ AMPA receptors stimulation by glutamate can activate AKT-dependent pathway, and this activation can regulate cell survival. ${ }^{36}$ An established cell line showed that $\mathrm{PKB} / \mathrm{AKT}$ may serve as an IKK kinase in response to TNF- $\alpha$ administration. ${ }^{34}$ I $\kappa \mathrm{B} \alpha$ is the prime target after AKT phosphorylation in the heterotrimeric I $\kappa \mathrm{B}$ kinase complex, resulting in I $\mathrm{K} B \beta$ activation and subsequent I $\mathrm{\kappa} \mathrm{B} \alpha$ phosphorylation. ${ }^{37}$ In the study, after KA administration, the neuron cultures of $\mathrm{KO}$ mice and WT mice with anti-TNF- $\alpha$ antibody blocking showed significantly lower phospho-IкB $\alpha$, AKT and phospho-AKT expression than WT mice cultures without anti-TNF- $\alpha$ antibody blocking; also, TNF- $\alpha$ stimulation increased phospho-IкB $\alpha$ and phospho-AKT production as compared to WT mice without TNF- $\alpha$ pre-exposure. We document that AKT pathway may also play the protective role in KA-induced neurotoxicity. However, in our study, after KA administration, there is no significant difference regarding total AKT expression among the neurons from WT mice exposed to rm-TNF- $\alpha$ with 50 and 100ng/ $\mathrm{ml}$ and WT mice without $\mathrm{rm}-\mathrm{TNF}-\alpha$ stimulation. This implies that phospho-AKT is more sensitive than total AKT to TNF-stimulation. These results demonstrated that the AKT signaling pathway may play an important role in TNF- $\alpha$-induced protection from KA-induced neurotoxicity.

\section{Conclusion}

In conclusion, TNF- $\alpha$ deficiency and blocking TNF- $\alpha$ activity enhanced KA-induced neurotoxicity, as demonstrated by elevated production of LDH and NO, and reduced cell survival. Simultaneously, the opposite result was observed following application of TNF- $\alpha$. Thus, TNF- $\alpha$ may play a protective role in KA-induced neurotoxicity via up-regulation of $\mathrm{NFKB}$ and $\mathrm{AKT}$ and down-regulation of $\mathrm{p} 38$ MAPK signaling pathways.

\section{Acknowledgements}

This work was supported by grants from the Gamla Tjänarinnor foundation; The Gun och Bertil Stohnes Foundation; the Swedish Society of Medicine Foundation; China Scholarship Council; the Faculty of Medicine \& Health Science, United Arab Emirates University; the Foundation for Geriatric Diseases at Karolinska Institute.

\section{Conflict of interest}

The author declares no conflict of interest.

\section{Refernces}

1. Liu T, Clark RK, McDonnell PC, et al. Tumor necrosis factor-alpha expression in ischemic neurons. Stroke. 1994;25(7):1481-1488.

2. Lee YB, Yune TY, Baik SY, et al. Role of tumor necrosis factor-alpha in neuronal and glial apoptosis after spinal cord injury. Exp Neurol. 2000;166(1):190-195

3. Carswell EA, Old LJ, Kassel RL, et al. An endotoxin-induced serum factor that causes necrosis of tumors. Proc Natl Acad Sci USA. 1975;72(9):3666-3670.

4. Taylor DL, Jones F, Kubota ES, et al. Stimulation of microglial metabotropic glutamate receptor mGlu2 triggers tumor necrosis factor alpha-induced neurotoxicity in concert with microglial-derived Fas ligand. J Neurosci. 2005;25(11):2952-2964.
5. Michalak S, Wender M, Michalowska-Wender G. Cachexia-induced cerebellar degeneration:involvement of serum TNF and MCP-1 in the course of experimental neoplastic disease. Acta Neurobiol Exp (Wars). 2006;66(2):113-122.

6. Ferguson AR, Christensen RN, Gensel JC, et al. Cell death after spinal cord injury is exacerbated by rapid TNF alpha-induced trafficking of GluR2-lacking AMPARs to the plasma membrane. J Neurosci. 2008;28(44):11391-11400.

7. Montgomery SL, Bowers WJ. Tumor necrosis factor-alpha and the roles it plays in homeostatic and degenerative processes within the central nervous system. J Neuroimmune Pharmacol. 2012;7(1):42-59.

8. Lambertsen KL, Clausen BH, Babcock AA, et al. Microglia protect neurons against ischemia by synthesis of tumor necrosis factor. $J$ Neurosci. 2009;29(5):1319-1330.

9. Scherbel U, Raghupathi R, Nakamura M, et al. Differential acute and chronic responses of tumor necrosis factor-deficient mice to experimental brain injury. Proc Natl Acad Sci USA. 1999;96(15):8721-8726.

10. Lee JK, Won JS, Singh AK, et al. Statin inhibits kainic acid-induced seizure and associated inflammation and hippocampal cell death. Neurosci Lett. 2008;440(3):260-264.

11. Deshpande LS, Lou JK, Mian A, et al. Time course and mechanism of hippocampal neuronal death in an in vitro model of status epilepticus:role of NMDA receptor activation and NMDA dependent calcium entry. Eur J Pharmacol. 2008;583(1):73-83.

12. Schinder AF, Olson EC, Spitzer NC, et al. Mitochondrial dysfunction is a primary event in glutamate neurotoxicity. J Neurosci. 1996;16(19):61256133.

13. Zhang XM, Zheng XY, Sharkawi SS, et al. Possible Protecting Role of TNF-alpha in Kainic Acid-induced Neurotoxicity Via DownRegulation of NFkappaB Signaling Pathway. Curr Alzheimer Res. 2013;10(6):660-669.

14. Fath T, Ke YD, Gunning P, et al. Primary support cultures of hippocampal and substantia nigra neurons. Nat Protoc. 2009;4(1):78-85.

15. Mosmann T. Rapid colorimetric assay for cellular growth and survival:application to proliferation and cytotoxicity assays. J Immunol Methods. 1983;65(1):55-63.

16. Vezzani A, Balosso S, Ravizza T. The role of cytokines in the pathophysiology of epilepsy. Brain Behav Immun. 2008;22(6):797-803.

17. Riazi K, Galic MA, Kuzmiski JB, et al. Microglial activation and TNFalpha production mediate altered CNS excitability following peripheral inflammation. Proc Natl Acad Sci US A. 2008;105(44):1715117156

18. Golan H, Levav T, Mendelsohn A, et al. Involvement of tumor necrosis factor alpha in hippocampal development and function. Cereb Cortex. 2004;14(1):97-105.

19. Zheng XY, Zhang HL, Luo Q, et al. Kainic Acid-Induced Neurodegenerative Model: Potentials and Limitations. J Biomed Biotechnol. 2011;2011:457079.

20. Chen Z, Duan RS, Quezada HC, et al. Increased microglial activation and astrogliosis after intranasal administration of kainic acid in $\mathrm{C} 57 \mathrm{BL} / 6$ mice. J Neurobiol. 2005;62(2):207-218.

21. Darstein M, Petralia RS, Swanson GT, et al. Distribution of kainate receptor subunits at hippocampal mossy fiber synapses. J Neurosci. 2003;23(22):8013-8019.

22. Lauri SE, Bortolotto ZA, Bleakman D, et al. A critical role of a facilitatory presynaptic kainate receptor in mossy fiber LTP. Neuron. 2001;32(4):697-709. 
23. Wang Q, Yu S, Simonyi A, et al. Kainic acid-mediated excitotoxicity as a model for neurodegeneration. Mol Neurobiol. 2005;31(1-3):3-16.

24. Wiesinger H. Arginine metabolism and the synthesis of nitric oxide in the nervous system. Prog Neurobiol. 2001;64(4):365-391.

25. Ueda Y, Yokoyama H, Nakajima A, et al. Glutamate excess and free radical formation during and following kainic acid-induced status epilepticus. Exp Brain Res. 2002;147(2):219-226.

26. Amor S, Puentes $\mathrm{F}$, Baker $\mathrm{D}$, et al. Inflammation in neurodegenerative diseases. Immunology. 2010;129(2):154-169.

27. Byun JS, Lee SH, Jeon SH, et al. Kainic Acid-induced Neuronal Death is Attenuated by Aminoguanidine but Aggravated by L-NAME in Mouse Hippocampus. Korean J Physiol Pharmacol. 2009;13(4):265-271.

28. Ware CF, Crowe PD, Vanarsdale TL, et al. Tumor necrosis factor (TNF) receptor expression in $\mathrm{T}$ lymphocytes. Differential regulation of the type I TNF receptor during activation of resting and effector T cells. $J$ Immunol. 1991;147(2):4229-4238.

29. Lu MO, Zhang XM, Mix E, et al. TNF-alpha receptor 1 deficiency enhances kainic acid-induced hippocampal injury in mice. $J$ Neurosci Res. 2008;86(7):1608-1614.

30. Yang L, Lindholm K, Konishi Y, et al. Target depletion of distinct tumor necrosis factor receptor subtypes reveals hippocampal neuron death and survival through different signal transduction pathways. $J$ Neurosci. 2002;22(8):3025-3032.
31. Xing B, Bachstetter AD, Eldik LJ. Microglial p38alpha MAPK is critical for LPS-induced neuron degeneration, through a mechanism involving TNFalpha. Mol Neurodegener. 2011;6:84.

32. Ghatan S, Larner S, Kinoshita Y, et al. p38 MAP kinase mediates bax translocation in nitric oxide-induced apoptosis in neurons. J Cell Biol. 2000;150(2):335-347.

33. Pasparakis M, Luedde T, Schmidt-Supprian M. Dissection of the NFkappaB signalling cascade in transgenic and knockout mice. Cell Death Differ. 2006;13(5):861-872.

34. Marchetti L, Klein M, Schlett K, et al. Tumor necrosis factor (TNF)mediated neuroprotection against glutamate-induced excitotoxicity is enhanced by $\mathrm{N}-$ methyl-D-aspartate receptor activation. Essential role of a TNF receptor 2-mediated phosphatidylinositol 3-kinase-dependent NF-kappa B pathway. J Biol Chem. 2004;279(31):32869-32881.

35. Hsu YY, Liu CM, Tsai HH, et al. KMUP-1 attenuates serum deprivationinduced neurotoxicity in SH-SY5Y cells:roles of PKG, PI3K/Akt and Bcl-2/Bax pathways. Toxicology. 2010;268(1-2):46-54.

36. Noch E, Khalili K. Molecular mechanisms of necrosis in glioblastoma:the role of glutamate excitotoxicity. Cancer Biol Ther. 2009;8(19):17911797.

37. Gustin JA, Ozes ON, Akca H, et al. Cell type-specific expression of the IkappaB kinases determines the significance of phosphatidylinositol 3-kinase/Akt signaling to NF-kappa B activation. J Biol Chem. 2004;279(3):1615-1620. 